\title{
Where are all the Media Librarians?
}

\author{
by Elizabeth Vidrine
}

0

ver the past eight years, a gap has formed in services offered by academic media resources libraries that contrasts starkly with advances in analogous higher education technology and support.

In 1999, when the American Library Association updated its Guidelines for Media Resources in Academic Libraries, audiovisual libraries showed signs of evolving with the times, but the administration and operation of media resources have generated concern. The message was clear: The librarian responsible for the media resources program should have a graduate degree from an ALA-accredited program in library or information science. ${ }^{1}$

Fast forward to 2005. Where are all the Media Resources librarians? Although there are a few librarians, many media collections fall between the cracks or are maintained by someone with more of an information technology background. For instance, the Consortium of College and University Media Centers (CCUMC) has as its slogan, "Addressing your changing role as an instructional technology and media professional in higher education." ${ }^{2}$ Other aspects of providing multimedia services, such as campus instruction, collection development and management, and emerging technologies, ${ }^{3}$ all fall within the scope of the consortium. CCUMC's mission statement is as follows:

The mission of CCUMC is to provide leadership and a forum for information exchange to the providers of media and technology support for quality teaching and learning at higher education institutions. Specifically, the consortium shall:

- advocate the accessibility and effective use of educational media.

- provide leadership in the development of standards for the effective implementation and management of instructional technology in higher education.

- foster cooperative efforts among colleges and universities and other institutions, agencies, foundations, and organizations in the solution of mutual problems.

- gather and disseminate information about educational, professional, and operational issues, including statistics important to the profession.

- develop and provide programs and services that will enable members to most effectively support the missions of their institutions.

- provide professional development opportunities for members.

- $\quad$ inspire, generate, and coordinate research and scholarship that advances the mission of CCUMC. ${ }^{4}$

So, how do other libraries handle multimedia library tasks and media instruction? Increasingly, reference personnel endeavor to compensate by taking on the responsibilities of a skilled media librarian, often without the experience and understanding brought about by years of helping patrons specifically with media resources and services.

The CCUMC also has a statement on collection development and management. Aren't these library terms? Why is there a separate organization undertaking this task? Is it because there is no one in the library to do it?

Why isn't there a professional organization within ALA analogous to the CCUMC? ALA has created a set of standards and guidelines for media resources libraries, but does it end there? The Video Round Table only addresses a small segment of the duties of an active media 
services librarian in a fast-paced library. Increasingly, student presentations are more digitally-based than paper-based. Students and faculty need assistance locating images and sounds, and instruction in their use, as well as copyright guidance. Does the CCUMC address these concerns? Does ALA?

One key component to this journey is the matter of technology. Currently, at one university, the IT (information technology) department addresses the needs of every department except the media library—not because they are unwilling, but because the needs of a media resources library are so different from the needs of the rest of campus. Even computer requirements are different; peripherals are out-ofthe-ordinary. Someone on campus needs to learn how to install the video capture card and software, and that someone may as well be the person who is expected to instruct others in how to use them.

\section{The duck-billed platypus: Media Professional vs. Media Librarian}

Issues related to information technology and media resources libraries merit further exploration because these matters seem to be handled differently at each library. So long as Microsoft PowerPoint is not going to disappear in the near future, perhaps it is time to take a closer look at what colleges and universities

are doing to see if there is a more efficient way of helping students and faculty fulfill their requirements for multimedia technology knowhow.

Launching an investigation of media library practices in colleges and universities warrants a narrower sample; therefore, a focus group of all the college and university libraries listed on the North Carolina State Library Web site was selected. ${ }^{5}$ Each Web site was visited to locate a media services librarian's e-mail address, or, barring that, collect the director's e-mail address.

The following questions were asked of each library representative:

1. Where on your campus do students and faculty go for help in incorporating multimedia into their projects?

2. Is there a media services librarian in your library? If not, under whose duties does it fall to maintain access to and collect media materials, and how do their talents complement their tasks? What is their job title?

3. Does your library offer assistance to students and faculty in creating instructional multimedia? If so, please explain.

4. Where on campus do you receive your Information Technology support (in-house or from another department on campus)?

So, how are libraries addressing the growing demand for media technology?

\section{The Results}

Of the libraries surveyed, only 25 percent did not offer any support for media presentations. Of the 75 percent that do, the responses included services being offered by the library or by the library in addition to other places on campus. Twenty-five percent responded that the library had a media department to assist students in using multimedia.

Of the 16 respondents, only two libraries had a librarian whose chief responsibilities were the media collections. Among the remainder, responsibilities are decentralized—collection development is responsible for the collection, cataloging is responsible for cataloging, and circulation is responsible for circulation.

One thing of note: many responses were from libraries with few staff; since many of the librarians were reference/director, or serials/ cataloging, etc., having multiple duties necessarily prohibited having one librarian responsible for campus media resources.

Forty percent of the responding libraries do not offer instruction for faculty and students in using multimedia, while 60 percent offer either comprehensive or limited assistance. 
Technological support comes from the IT department for 33 percent of the respondents, while the majority of libraries surveyed said that they performed most support on their own, relying on campus IT offices for what they could not do. Twenty percent of libraries surveyed are self-sufficient and do not receive campus IT assistance.

What this information demonstrates is that each institution does things a little differently. What may work for some may not work for all; of course, it's not a one-size-fits-all scenario. Perhaps it is time to re-examine library services to see how they can be improved.

In a recent article, Gregory A. Mitchell emphasizes the rapidly expanding role of multimedia in education:

\begin{abstract}
Multimedia has begun to attract attention in the library community. Joe Janes, chair of Library and Information Science at the Information School at the University of Washington and the person responsible for developing the Internet Public Library, recently stated he foresees a growing role for multimedia in the library. It will replace much of the traditional, text-based communication that people are accustomed to. For example, multimedia projects can become the research paper of the future for students. It is the media in which many library customers will be working. ${ }^{5}$
\end{abstract}

With 75 percent of North Carolina libraries surveyed assisting patrons with incorporating multimedia into their projects and 60 percent offering instruction in using multimedia, it seems that libraries do recognize the important and evolving role technology is playing in higher education. With so many libraries doing their own technical support, they should be capable of expanding services to include presentation support. Should libraries evolve, or should the responsibility lie elsewhere?

Mitchell points out several good reasons why media instruction should take place in the academic library:

- Not only is it in a central location, it is also open more hours than other places on campus

- Many of the sources students utilize in their presentations are housed in the library

- Librarians are very service-oriented, and

- Offering media instruction will offer up new challenges and opportunities for librarians to create projects for the library. ${ }^{6}$

With many campuses lacking a centralized location for assisting students with media technology, and with the growing trend for creating multimedia-rich projects, perhaps now is a good time to re-evaluate the types of services today's academic library provides. Comprehensive multimedia services is a niche that has yet to be filled in many academic libraries.

\title{
References:
}

${ }^{1}$ ACRL Media Resources Committee. "Guidelines for Media Resources in Academic Libraries." April, 1999. < http://www.ala.org/ alalacrllacrlstandards/ guidelinesmedia.htm> (July 2005).

${ }^{2}$ Consortium of College and University Media Centers. "CCUMC Home Page." < לttp://www.ccumc.org > (July 2005).

${ }^{3}$ Consortium of College and University Media Centers, "CCUMC Mission.” March 8, 2000. < http://www.ccumc.org/govern/ mission. html> (July 2005).

${ }^{4}$ Consortium of College and University Media Centers, "About CCUMC." August 7, 2000. < http://www.ccumc.orglabout.html> (July 2005).

${ }^{5}$ North Carolina State Library, "NC Colleges and Universities on the Web." September 20, 2004. <http://statelibrary.dcr.state.nc.us/ library/univers.htm> (July 2005).

${ }^{6}$ Mitchell, Gregory A. "Distinctive Expertise: Multimedia, the Library, and the Term Paper of the Future," Information Technology and Libraries 24 (March 2005): 32-36. 